\title{
Analysis of China-Africa Relations: Historical Development and Current Perspectives
}

\author{
Issa Kansaye \\ School of Politics and Law, Northeast Normal University, 5268 Renmin Street, \\ Changchun City, Post code: 130024, Jilin Province, China
}

\begin{abstract}
This paper examines China-Africa relations by discussing how the ties have evolved over time, current perspectives, reasons for China's venture into Africa and how African governments have benefited from this cooperation. China's robust presence in Africa is an area of interest that has attracted, generated and sustained a lot of scholarly debates. China's venture in Africa goes back to the 1950 s when most African countries were fighting for independence from colonial masters. China aims at building a win-win type of co-operation. Currently, China is investing on the African continent in terms of funding massive infrastructural projects, cultural exchanges, trade, higher education etc. African governments look up to China as an old diplomatic and development partner and aspire to emulate its model of economic development. However despite these, China's increasing dominance in Africa has received a lot of criticism from western countries. They consider China's continued and increasing presence on the African continent as a form of neo-colonialist predatory tendency. Supporters of the Sino-African relations on the other hand argue that the Chinese model applied in Africa is similar to models used by Europe and the United States of America. China's policy of development without interference has often been misunderstood to imply indifference. This paper therefore explains the win-win type of co-operation between China and African governments.
\end{abstract}

Keywords: China-Africa relations, historical development, current perspectives

DOI: $10.7176 /$ RHSS/11-2-04

Publication date: January $31^{\text {st }} 2021$

\section{I.0 Introduction}

The study of China-Africa relations has been approached from a wide array of disciplines. Three theoretical perspectives are now common in the literature: Realism, Liberalism and Social Constructivism. Realism sees China's engagement in Africa as driven by its national interest centered on economic and geo-strategic interests, liberalism views the engagement in Africa as a consequence of globalization rooted in China's domestic modernization program that began in the late 1970s. Social constructivism draws inspiration from historical interaction between China and Africa, viewing the engagement as shaped by identities and shared interests over time (Otele, 2020). China is both a long-established diplomatic partner and a new investor in Africa. Chinese interests on the continent encompass not only natural resources but also issues of trade, security, diplomacy, and soft power. China is a major aid donor, but the scope, scale, and mode of Chinese aid practices are poorly understood and often misquoted in the press. Most analyses of Chinese engagement with African nations focus on what China gets out of these partnerships - primarily natural resources and export markets. Some studies have described the impacts, positive and negative, that China's aid and investment policies have had on African countries. However, few analyses have approached Sino-African relations as a vibrant, two-way dynamic in which both sides adjust to policy initiatives and popular perceptions emanating from the other (Hanaver \& Morris, 2014). The dramatic growth in the relationship between Africa and China is one of the great stories of the twenty-first century, part of the profound transformations taking place in the global political economy. It has been greeted with excitement, consternation, and confusion. To its cheerleaders, it represents the enduring partnership between Africa and China, spawned by the historical affinities of struggles against Western imperialism and humanistic aspirations for development. To its critics, it is reminiscent of European colonization a century earlier, in which Africa serves as a cheap source of raw materials, a lucrative export market for Chinese manufactured goods, and an outlet for its surplus capital. Rather than a development partner, some see China as Africa's biggest development competitor, whose explosive growth and insatiable quest for global markets threatens Africa's industrialization and competitiveness (Zeleza, 2014). The impact of China's presence on the African sub-continent is an issue that needs deep and honest scholarly research and engagement. The Sino-African relations are complex and dynamic in nature and therefore need to be examined right from historical to modern times to develop deeper understanding.

\subsection{Historical Development}

China's involvement in African affairs dates back to the 1950s. This time marked the beginning of African states breaking free from the yoke of colonialism. China's relationship with Africa in modern times is thus characterized by the former supporting liberation movements that had then been in momentous stages leading to independence of most African countries from the colonial masters in the 1960s. Initially, China's support was mainly motivated 
by ideology, but this would change in the coming decades. A major shift in the dynamics of the China-Africa relationships came about in the 1980s when China embarked upon its "Opening up and Reform Policy" -a wideranging policy that gave birth to the new China as we know it today. Economic and geo-strategic interests rather than the desire to export a specific political philosophy drive China's current relationship with Africa. The intensity of relations also changed: with its increasing economic and political power as well as hunger for resources China's relations with Africa intensified (Berhe, 2013).

Alden \& Wu (2017) observe that China's co-operation with Africa is not a new development as their relations date back to centuries ago to as far as (1368-1644) during the Ming Dynasty. During this time, Chinese explorers toured Eastern Africa under the command of admiral Zheng who was an explorer, mariner and diplomat. The founding of the People's Republic of China in 1949 propelled for more robust and progressive engagements between China and Africa. From the second quarter of the 1950s, China's relations with Africa started to take shape and were further spearheaded by the fact that some African states were gaining or about to gain their freedom from their respective European colonizers (Alden \& Alves, 2008). According to Plummer (2003) these unfolding events presented Beijing with the platform to fully engage with African countries with regards to diverse investment opportunities. An important moment in cementing the Sino-African relations was achieved during the Bandung Conference of 1955. This conference brought together Asian, African and Middle East Countries and was viewed as a perfect platform to further enhance Asian-African cooperation (Stahl, 2016). During the conference, former foreign minister Zhou Enlai for China had the privilege to fully engage with African heads of states and stressed that Africa and Asia had to work as collectively through economic, cultural and mutual benefits in order for them to improve their level of development. After the Bandung conference, Chinese delegates increased diplomatic visits to African countries. Zhou Enlai spent seven weeks in ten African countries to intensify Africa-China relations through diplomatic driven missions from December 1963 to February 1964 (Shengnan, 2014).

As a result of these diplomatic visits, in the same year (1964) China had already secured bilateral agreements with six African states. From 20 December 1982 to 17 January 1983, eleven African countries were also paid a visit by former Chinese premier Zhao Ziyang to further strengthen South-South cooperation (Alden \& Alves, 2008).

Basically, the Bandung conference presented China with the prospect to make substantial inroads to African territories (Alden \& Alves, 2008).Over the years institutes such as the China-Africa joint research exchange plan, China - Africa people to people friendship action and China-Africa youth festival have jointly been established by Beijing and African countries as a tool of further stimulating their relations (Eisenman \& Heginbotham, 2018; Shinn \& Eisenman, 2012). According to Taylor (2011) in the year 2000, the Chinese government established the Forum on China-Africa Cooperation (FOCAC) as a mechanism to further stimulate and strengthen China-Africa partnerships (economically, politically and infrastructural). FOCAC aims to forge cooperation between African and China through South-South cooperation and to further promote China's long-term plans for African development. The FOCAC provides a unique and genuine opportunity for both parties to mold their relationship in a way that serves their long-term interests on the basis of mutual benefits, respect and equality. China's importance in African politics, governance and development is growing. The launching in the wake of the $21 \mathrm{st}$ century of the Forum on China-Africa Cooperation (FOCAC), coupled with the increasingly higher participation of African Heads of State and Government in the Forum, is evidence to the enhancement of the China- Africa partnership. The attendance of a record 42 African Heads of State and Government at the 5th FOCAC meeting in Beijing attracted much attention among the international community (Berhe, 2013). In the year 2000, a newly formed FOCAC sought to establish a framework for China to co-ordinate its multiple diplomatic relationships with African nations. As of 2017, every African country was a member of the forum (Tobenkin, 2019). This demonstrates the greater length African governments are willing to go in order to strengthen their ties with China.

\subsection{Current Perspectives}

China's rapid rise as an Asian and Global superpower over the last few decades has attracted much attention from both scholars and policy analysts alike. It has gained so much prominence as a new global investor that is seen as a new challenger to the United States of America (USA), particularly as a result of its rapid investments (trade, aid, infrastructural development and information and communication technology) drive in Africa (Stahl, 2016). According to Mlambo, Kushamba \& Simwamu (2016) Chinese investments in Africa include but not limited to the financing of large infrastructural projects, ever-increasing loans, debt cancellation, assisting in nurturing human resources and granting African states the chance to access Chinese markets and as a result often filling the void in substantial components such as infrastructure and trade. Large (2008) observes that over the years and particularly from the 1950s, China has gained noticeable footsteps in Africa through its foreign policy, such that it has dramatically reduced the monopolistic of Western countries that have enjoyed massive footprints in Africa since the era of colonialism. China has emerged as a major development partner on the post-independence African frontier. Most African countries are turning to the East as opposed to the West as was in the past. 
According to Hogwe \& Banda (2017) China is currently viewed as one of the fastest emerging global power in the world and has often been compared to South Africa, India, Russia and Brazil. However, unlike these countries it is compared with, China has undertaken immense investments in Africa over the past three decades (Song \& Golley, 2011). These have been spearheaded by China's Official Development Assistance (ODA) and its foreign policy to be a new donor to Africa's development as the continent is in dire need of Foreign Direct Investments (FDI) for its economic growth frameworks. Beijing has thus regarded Africa as a continent where it can extract its resources and the platform for Chinese firms to build their plant(s) and create employment opportunities (Thrall, 2015). Tull (2006) argues that unlike western funding mechanisms which are more focused on reducing poverty levels in the continent, China is heavily focused on infrastructural and trade, a move that is often warmly received by African leaders. Apart from these investments, Beijing does not impose any political obligations in its dealing with African states and regularly invest in sectors where western donors are reluctant to (Ayodele \& Sotola, 2014).Over a decade ago in May 2005, former Zimbabwean president Robert Mugabe articulated that "We have turned East where the sun rises and given our backs to the West, where the sun sets" these words were as a result of the renowned appreciation of the FDI from China not only to Zimbabwe but African in general (Mugabe, 2005). China's opening up and re-discovery of Africa coincided with Africa's deteriorating economic performance as a result of conflicts, mismanagement as well as structural adjustment policies. China brought a viable alternative of social, political and economic development formula to the uni-polar world of the 1990s. Frustrated by complex donor policies and the high overhead costs of multilateral development projects, African governments continue to appreciate the alternative presented by China in an increasingly multipolar world (Berhe, 2013).

China-Africa relations have also spilled over to the field of Higher Education. Most news about China in the field of international education tends to be about outbound students. But in 2014, China quietly surpassed the United Kingdom and the United States as a top destination for international students from Africa- and it continues to draw increasing numbers of students from the continent (Tobenkin, 2019). China's place as a top destination for African tertiary international students is the product of a concerted effort. A multi-pronged approach that actively promotes Chines culture and language diffusion throughout the African continent, supports African national Higher Education efforts, and fosters diverse and dynamic intergovernmental and inter-institution tertiary efforts. To create a robust presence within African Higher Education institutions, China established a network of Confucius Institutes which operate in other countries around the world, are non-profit public education organizations affiliated with the Chinese Ministry of Education. Their stated goals are to promote Chinese language and culture, support local Chinese teaching abroad internationally, and facilitate cultural exchanges (ibid.). China has managed to attract many international students of African descent because of the many scholarships it offers and also the fees charged by universities are affordable compared to the United States and other universities in Europe. This explains the current trends of cross boarder education between China and Africa. This trend has however been criticized as being one sided because very few Chinese students go to Africa to pursue Higher Education.

However, Chinese investments in Africa have not come without controversies. According to Zeleza (2014) Beijing's investments in Africa have often been challenged as a result of biased competitive and investments procedures, safety concerns for African workers, low wages, inability to duly comply with local labour laws and practices, incapable to attract and nature African workers and at times employing dictatorship rule in management positions. Furthermore, small African businesses are severely affected by Chinese imports as a result of them being cheap and easily available. It has also been said that China does not adhere to enhance good governance in Africa due to the fact that it does not release accurate data on investments and aid undertaken in the continent (Jahanzeb \& Muneer, 2012; Sauls \& Heaton, 2016). Zhao (2014) notes that while China has found niches based on its comparative advantages and gained a solid ground in Africa, it's almost single-minded way of pursuing business interests without regard to many issues of local and international concern has caused backlashes. Learning lessons the hard way, China has made efforts to adjust such insensitive business practices in recent years, motivated by its changing economic and strategic interests. Hanaver \& Morris (2014) also observe that Beijing has adjusted its policies to assuage Africans' concerns and put the Sino-African relationship on a more balanced footing. These modifications include a greater emphasis on sustainability in the economic and trade relationship; the promotion of Chinese soft power, culture and people-to-people exchanges; and proactive engagement in the security and stability of conflict-prone areas in Africa.

These developments beg the question whether the China-African relations are mutual or asymmetrical? Who is benefitting more than the other? China or Africa or both? From the literature presented above, it is clear that both China and Africa consider their co-operation as mutual. Besada (2013) argues that what is being by done by Beijing in terms of African investments is what any global player would do as the case with various European countries and the USA. Sino-African relations are a vibrant two-way dynamic, in which both sides adjust to policy initiatives and popular perceptions emanating from the other (Hanaver \& Morris, 2014). Hanaver \& Morris (2014) assessed Chinese and African goals, African perceptions of China, how China has adjusted its policies to address 
local reactions, whether the United States and China compete in the region, and how Washington and Beijing might actually co-operate for mutual benefit. African governments look to China to provide political recognition and legitimacy and to contribute to their economic development through aid, investment, infrastructure and development, and trade. Some Africans aspire to replicate China's rapid economic development and believe that their nations can benefit from China's recent experience in lifting itself out of poverty (ibid). It is clear that both China and African have the feeling that their co-operation is mutually beneficial even though their relations have received serious criticisms from opponents.

\subsection{Methodology}

This study used the qualitative approach to research. Data was collected mainly from secondary sources. These included journal articles, books and other publications. The relevant data collected from these sources was subjected to content analysis. Qualitative research techniques include small-group discussions for investigating beliefs, attitudes and concepts of normative behavior; semi-structured interviews, to seek views on a focused topic or, with key informants, for background information or an institutional perspective; in-depth interviews to understand a condition, experience, or event from a personal perspective; and analysis of texts and documents, such as government reports, media articles, websites or diaries, to learn about distributed or private knowledge (Hammarberg, K., Kirkman, M. \& De Lacey, S., 2016).

\subsection{References}

Alden, C. \& Alves, A.C. (2008). History and Identity in the construction of China's African Policy. Political Economy, 35(15), 45-48.

Alden, C. \& Wu, Y.S. (2017). China Africa -Fact Sheet. Available at: http://www.saiia.org.za/specialpublications-series/694-2015-china-africa-factsheet/

Berhe, M.G. (2013). China-Africa Relations: Governance, Peace and Security. Ethiopia Institute for Peace and Security Studies (Addis Ababa University) and Institute of African Studies (Zhejiang Normal University).

Besada, H. (2013). Assessing China's Relations with Africa. Africa Development, 38(1-2), 81- 105.

Duggan, N. (2020). Competition and Compromise among Chinese Actors in Africa: A Bureaucratic Politics Study of Chinese Foreign Policy Actors. Palgrave, Macmillan.

Hammarberg, K., Kirkman, M. \& De Lacey, S. (2016). Qualitative research methods: when to use them and judge them. Human Reproduction, 31(3), 498-501.

Hanaver, L. \& Morris, L.J. (2014). China Africa: Implications of a Deepening Relationship. Available at: https://www.rand.org/pubs/research-briefs/RB9760.html

Hogwe, F. \& Banda, H. (2017). The nature of China's role in development of Africa: The Case of Zimbabwe. Problems and Perspectives in Management, 237-247.

Mlambo, C.T., Kushamba, A. \& Simwamu, M.B. (2016). China-Africa Relations: What Lies Beneath? The Chinese economy, 49(2), 257-276.

Mugabe, R.G. (2005) in Bauer, J. (2013). The Flight of the Phoenix: Investing in Zimbabwe's Rise from the Ashes during the Global Debt Crisis. Berlin, Epuli Gmbtt.

Otele, O.M. (2020). China-Africa Relations: Interdisciplinary Question and Theoretical Perspectives. The African Review, 47(2), 267-284.

Plummer (2003). Window on Freedom: Race, Civil Right and Foreign Affairs, 1945-1988. Chapel Hill, The Universityof North Carolina Press.

Sauls, P.R. \& Heaton, N.D. (2016). Consequences of Chinese Aid in Sub-Saharan Africa. Master's thesis. Naval Postgraduate School, the United States of America.

Song, L. \& Golley, J. (2011). Rising China: Global Challenges and Opportunities. Canberra, The Australian National University Press.

Stahl, A.K. (2016). China's Relations with Sub-Saharan Africa. Available at: http://www.iai.it/sites/default/files/iaiwp/622.pdf

Thrall, L. (2015). China's expanding Africa Relations: Implications for US National Security. Santa Monica, Rand Corporation.

Tobenkin, D. (2019). China's Influence in Africa: A Rising Tide: Chinese Investment across the continent yields results in Higher Education. International Educator. Available at: https://www.nafsa.org

Zeleza, T.P. (2014). The African-China Relationship: Challenges and Opportunities. Canadian Journal of African Studies 48(1), 145-169.

Zhao, S. (2014). A neo-colonialist predator or development partner? China's engagement and rebalance in Africa. Journal of Contemporary China, 23(96). 